\title{
Psicanálise e Literatura - Imre Kertész* e o desterro humano
}

No dia 23 de outubro de 2015, coincidindo com a celebração do $59^{\circ}$ aniversário do levante húngaro contra o regime stalinista ocorrido em 1956, o Instituto de Psicologia da USP, através de seu Departamento de Psicologia Clínica, promoveu o lançamento do livro, em formato e-book, organizado por José Alberto Cotta e Gilberto Safra: Psicanálise e Literatura - Imre Kertész e o desterro humano. Entre diversos convidados, deram seus depoimentos a professora Sarolta Kóbori, responsável por ministrar o curso de língua e cultura húngara na FFLCH/USP, e Paulo Schiller, psicanalista e tradutor, entre outros, de Imre Kertész.

Em poucos minutos, numa apresentação fartamente ilustrada, Kóbori elencou os principais eventos da história da Hungria que ajudam na compreensão da crise de identidade que esse país milenar tem como tarefa resolver no século XXI. Ao contar sobre as trágicas circunstâncias em que um dos importantes poetas da Hungria do século XX desapareceu - Miklós Radnóti -, Kóbori passou o bastão para Schiller que, então, descreveu não somente sua experiência de tradutor literário de autores húngaros do quilate de Radnóti, Sándor Márai e Imre Kertész, entre outros, como também contribuiu com sua experiência no campo clínico.

Considerando a temática especial desta edição da Cadernos de Literatura em Tradução, acredita-se que estas duas palestras irão enriquecer o panorama que dá pano de fundo à literatura produzida pela "outra Europa", pois as questões nelas tratadas, apesar de dizerem respeito a um autor húngaro em especial, são exemplares a toda região.

Palavras Chave: Imre Kertész, desterro humano, Hungria

* Nobel de Literatura de 2002. 